\title{
THE LATEST TRENDS IN ORGANIZED RETAILING IN INDIA
}

\author{
Suresh Mallya $L^{1}$. and Dr.Prabhu N.R.V ${ }^{2}$ \\ ${ }^{1}$ Assistant Professor, Department of Management Studies, Valliammai Engineering College, Kattankulathur, and \\ Ph.D. Research Scholar, Dr.MGR University, Chennai. \\ ${ }^{2}$ Dean, School of Management, Prist University, Thanjavur and also Director, Chennai Campus, Prist University. \\ Email: drnrvprabhu@yahoo.com
}

\begin{abstract}
As we all know that Information Technology is playing a major role for India's current 9.2 GDP growth. Organized retailing in India is one more example for its open economy. India has been rated as one of the most attractive emerging markets for retail for last two years. It directly impacts only a small minority of Indian population while organized retail affects every single Indian and every sector of Indian society. Organized retailing is growing about 18-20 per cent per annum and new formats are emerging to deliver value to the consumer. The paper throws light on the slow evolution of retail market over the years in India and its contribution for economic growth. Mall is the latest format in the organized retailing; a significant development has occurred in last couple of years due to change in consumer profile and spending Behaviour. In 2003 there were 25 operational malls in the country and the number is forecasted to rise to a 220 by 2006 and 600 by 2010 . The likely positive impact of this revolution in different sectors is enumerated. The central idea of this paper is on how this retail boom would help the markets in India.
\end{abstract}

Keywords: Enterprise Performance Management; High Performance Business, Customer satisfaction, etc.

\section{Introduction}

\section{AN OVERVIEW OF THE RETAIL SECTOR}

The Indian retail sector is highly fragmented with $97 \%$ of its business being run by the unorganized retailers like the traditional family run stores and corner stores. The organized retail however is at a very nascent stage though attempts are being made to increase its proportion to $9-10 \%$ by the year 2010 bringing in a huge opportunity for prospective new players. The sector is the largest source of employment after agriculture, and has deep penetration into rural India generating more than $10 \%$ of India's $\mathrm{GDP}^{2}$

\section{Comparative Penetration of Organized Retail}

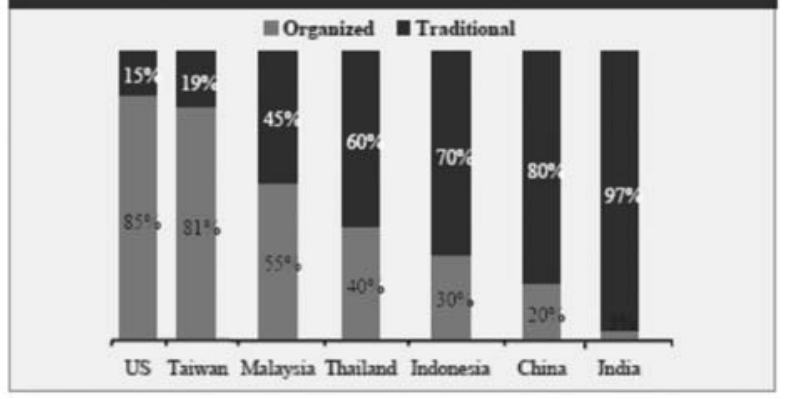

Source: Ernst \& Young, The Great Indian Retail Story, 2006.
A look at the statistics shows that the retail sector in India is worth USD 394 billion and is growing at the rate of $30 \%$ annually. An ICRIER study has found that retailing ( $\$ 180$ billion) contributes to 10 per cent of GDP and employs 7 per cent (21 million) of the workforce 3. According to AT Kearney, India is given the top ranking as the next foreign investment destination, as markets like China become increasingly saturated ${ }^{4}$. India is the $4^{\text {th }}$ largest economy as regards GDP (in PPP terms) and is expected to rank $3^{\text {rd }}$ by 2010 just behind US and China ${ }^{1}$. Over the past few years, the retail sales in India are hovering around $33-35 \%$ of GDP as compared to around $20 \%$ in the US. The table gives the picture of India's retail trade as compared to the US and China.

Organized retailing is growing about $18-20$ per cent per annum and new formats are emerging to deliver value to the consumer. Mall is the latest format in the organised retailing; a significant development has occurred in last couple of years due to change in consumer profile and spending behaviour. In 2003 there were 25 operational malls in the country and the number is forecasted to rise to a 220 by 2006 and 600 by 2010. Key challenges are there to operate such a significant number of malls, owing to heavy investment and getting the right operation. The organized retailing 
in India has just crossed Rs.200 billion marks and is growing at a rate 18- 20 per cent. But the share of organized segment is barely two per cent. India has also been rated as one of the most attractive emerging markets for retail for last two years. This major transformation in outlook is due to improved living standard and continuing economic growth. Therefore the future of organized retail is pretty bright.

Though Mall is the latest format in the organized retailing, a significant development has occurred in last couple of years due to change in consumer profile and spending behaviour. Increasing youth population with more purchasing power and less time is looking for shopping along with entertainment as one stop option. The immediate impact is very much evident from the drastic rise in forecast of 25 operational malls in 2003 to 220 by 2006 and 600 by 2010 . Non-metros are also participating equally to make this happen true. The major problem in organized retailing is the availability of quality retail space at a reasonable price. Mall is the solution, which has emerged to this growing problem.

We have made sufficient progress on the raw materials front. Productivity of cotton has gone up from about $300 \mathrm{~kg}$ per hectare a few years back to over $500 \mathrm{~kg}$ per hectare and cotton production has reached an all time high record of 280 lakh bales this year. In garments and home textiles, organized production has been picking up, though not fast enough. In the case of fabrics, however, we have not been able to keep pace with the changes in demand trends. Organized weaving does not have a share of even $5 \%$ in our fabric production. The processing segment has been seeing some increase in investments. But again, a major portion of our fabrics continue to get processed in the hand processing segment. With increasing pressure on prices, cost reduction assumes extra importance. Scaling up production facilities is the key for optimizing cost through effective utilization of modern technology. The Scheme for Integrated Textile Parks and TUFS are positive policy inputs from the government for making this feasible. Power at affordable prices as well as acceptable quality and workable labour laws are the important inputs still lacking.

\section{MERGER AND ACQUISITION ACTIVITY}

India witnessed a record number of M\&A deals in the first half of 2006, which were collectively worth USD 25.6 billion. A significant number of deals have being carried out in the Indian retail sector in the past few months in order to acquire a larger share in the growing domestic market and to compete against the prospective global and domestic players. The table below shows some recent deals that have taken place in the Indian retail sector:

TABLE ON RECENT DEALS IN THE INDIAN RETAIL SECTOR

\begin{tabular}{|l|l|l|l|c|c|}
\hline Year & $\begin{array}{c}\text { Acquired/JV } \\
\text { Company/Target }\end{array}$ & \multicolumn{1}{|c|}{ Acquirer } & \multicolumn{1}{|c|}{ Nature of Business } & Stake & $\begin{array}{c}\text { Consideration } \\
\text { (US\$ million) }\end{array}$ \\
\hline 2005 & Liberty Shoes & Future group & Retail (Footwear) & $51 \%$ & 3 \\
\hline 2005 & $\begin{array}{l}\text { Indus - League } \\
\text { Clothing }\end{array}$ & Future group & Retail clothing & $68 \%$ & 5 \\
\hline 2005 & Odyssey India & Deccan Chronicle Holdings & $\begin{array}{l}\text { Leisure retail chain (books, } \\
\text { music, toys) }\end{array}$ & $100 \%$ & 14 \\
\hline 2005 & Landmark & Tata Trent & Books, music, accessories & $74 \%$ & 24 \\
\hline 2006 & Bistro Hospitality & $\begin{array}{l}\text { TGl Friday's (a subsidiary } \\
\text { of Carlson Restaurant } \\
\text { World-wide) }\end{array}$ & Restaurant (Food retail) & $25 \%$ & N/A \\
\hline & $\begin{array}{l}\text { Indus League } \\
\text { glothing (Future } \\
\text { group company) }\end{array}$ & Etam group, France & $\begin{array}{l}\text { Lingerie and women's wear } \\
\text { retailing }\end{array}$ & $\begin{array}{c}50 \% \\
\text { (JV) }\end{array}$ & 8 \\
\hline
\end{tabular}

Source: Price Waterhouse Coopers, Asia-Pacific M\&A Bulletin, Mid year 2006. 


\section{FACTS OF ORGANIZED RETAILING IN INDIA}

Indian retail industry in 2003-04 was about Rs.10,916.2 billion, contributing ten per cent of the country's GDP and employing about ten per cent of the total labour force. But only two per cent of that comes in the organized segment. As compared to this, countries like USA (85 per cent), Malaysia (55 per cent), Thailand (40 per cent) and China ( 20 per cent) have a much higher proportion of retail in this segment. However, the organized segment is growing at a rate of 18-20 per cent, which is far higher than the overall market. A.T. Kearney has ranked India as the most attractive retail destination among emerging markets globally, ahead of China despite the ban on Foreign Direct Investment (FDI) in the sector and a relatively low market attractiveness of the country. Therefore the future of organized retail is pretty bright in India.

According to a study by KSA Techno Park, 88 per cent of the organized retail distribution was concentrated in the top six cities (i.e. NCR, Mumbai, Chennai, Kolkata, Hyderabad and Bangalore) and the remaining 12 per cent is from next four cities i.e. Ahmedabad, Pune, Jaipur and Lucknow in the year 1999. These cities have mature markets, supported by immense competition, good infrastructure and high consumer awareness. However, retailers have started focusing on the secondary cities also. KSA Technopark predicts that by the year 2005, the concentration in the top six cities will fall to 66 per cent and for the other four cities; it will increase to 20 per cent.

\section{Changing Dynamics of Indian Retail}

\section{Consumer Profile}

With the opening of economy Indian consumer has now a plethora of options coupled with higher purchasing power. He is more aware about how to satiate a need with exposure to media. Though India ranks very high as far as savings rate is concerned the recent developments saw personal consumption in a rising spree. There is an evolution of new breed of customer segments with breaking up of joint families and the increasing number of working couples.

With increasing purchasing power of the middle class and the growing professional working-woman, the buying habit has altogether taken a shift by more income and less time. As the dual income group is taking a better shape in India and the workingwomen are spending more time in the office than home so the demand for time management is high. The working class women love to go for enjoying their food outside home. Either they go for processed food like ready to each chapatti and ready to cook curry or they prefer to take food in first food chains or hotels. In the changing scenario, consumer demands for more convenience and quality service at affordable price. Apart from that today's highly demanding work culture leaves little time and option for leisure activity. All these led to a strong trend in favour for one-stop destination like malls and hypermarkets. A mall not only offers high quality shopping environment but also provides quality product assortment available at different shopping formats. Even some of the mall developers prefer to allocate a large part of the mall space for leisure and entertainment. Here shopping is no more a mundane activity of yester years but it's a pleasant experience coupled with entertainment called Shopertainment.

\section{Focus on Core Competency}

In order to run a retail venture successfully, apart from the core activity, maintenance and management of the place is also important. There is also a need to develop the place as a marketing destination. This needs a coordinated and cooperative long run center wide retailing strategy. Shopping centers as contrast to office buildings don't merely lease out space; on the contrary they are complex retail businesses whose sole focus is the sale of merchandise. Therefore, it is critical for the mall developers to find out right kind of tenant mix to offer wider assortment variety within the mall. Developing malls is not very difficult at this point of time as the government relaxed foreign investment in the real estate development. The bigger and the larger issues are to manage these malls with efficiency and effectiveness. Mall developers face difficulty is managing malls rather than developing malls. The mall developers need to look at customer benefits along with their benefits. Before deciding the anchor store they have to look at the customer profile in those catchments. Right tenant mix is one of the important factors for pulling shoppers into the shopping mall. As there is going to be rapid growth in organized retail in India and national level retailers are looking for strategic location for their store then it complicates issue further while deciding an anchor store. Under such circumstances mall developers need to understand the value proposition they are going to deliver both to shoppers and retailers. They should 
match the shoppers' requirement with the retailers' product offerings.

\section{Investment Opportunity}

With falling interest rates real estate poses to be the big investment destination. Growth of modern retail formats driving the retail space development across the country and malls have managed to remain profitable due to its high occupancies and rents.

\section{Entry of Foreign Players}

The big Indian retail players include Shopper's Stop, FoodWorld, Vivek's, Nilgiris,

Pantaloon, Subhiksha, Ebony, Crosswords, Planet Health, Lifestyle, Globus, Barista, Qwiky's, Café Coffee Day, Wills Lifestyle, Titan, Raymond, Bata and Westside. Most of the Indian retailers those who started early have access to prime shopping locations. For example retailers like Pantaloon, Westside, Planet Health, Crossword and Star Bazaar have prime locations in the city where the footfall is high and normally these areas remain crowded. But now the trend is changing, as the retailers would like to be a part of shopping mall where they can expect better shopping environment with adequate footfall to make the business viable. As of now the big retailers like Wal- Mart, Tesco and Aldi are not allowed to open their shop in India but in January 2006 Indian government allowed 51 per cent investment in the single brand outlet. That is going to open whole lot of scope for single branded retailers like Body Shop, Nike and Adidas. Next couple of years will be crucial for Indian retail sector as the possibility of opening up the retail sector for the foreign players is gathering momentum and that may bring much needed investment in retail infrastructure development. At this juncture of time infrastructure development is on right track and government and private participation in developing world-class special economic zone (SEZs) in India is on the way. Reliance is planning to use SEZs for its retail and distribution activity in future.

\section{The impact of India's retail revolution}

If India's much anticipated retail revolution has a start date, it could well be the first week of November 2006. On November 3, in a classic RIL move marked by scale and ambition, Reliance Retail launched 11 Reliance Fresh retail outlets simultaneously in the southern Indian city of Hyderabad, firing the first salvo in what will be a keenly contested battle to win a huge prize - nothing less than the wallets of Indian consumers!

\section{A Large \& Fragmented Retail Market}

According to KSA Technopak, a consultancy firm, the Indian retail market is projected to grow from US\$300 Billion in 2006 to US\$637 Billion by 2015 as GDP rises from US\$804 Billion to US\$1.7 Trillion over the same period. The bulk of the market is unorganised with less than $5 \%$ being classified as "modern trade". Even existing modern retail chains are typified by weak business processes and IT, poor supply chain management, undercapitalisation and under-investment. The urban market is $45 \%$ of India's retail market, with the top 784 cities alone accounting for US $\$ 105$ billion in retail sales. The rural market is dispersed over 627,000 villages, though it has a concentration around a core 100,000 villages that account for $50 \%$ of the rural population.

\section{Domestic Player Move to Grab Turf}

While global majors think through their India strategy, local companies are not wasting any time to get going. The top 10 players are expected to pump in close to US\$20 billion in investment in five years to achieve revenue of between US\$50-60 billion. The share of the modern trade is expected to rise to $18 \%$ within five years.

Reliance alone plans to invest over US\$5.5 Billion in its retail venture, targeting sales of \$22 Billion in five years through a national chain of hypermarkets and supermarkets in over 700 cities and 6,000 small towns across India. Reliance Fresh targets the large food \& beverage segment with a USP of low prices, wide range and fresh produce. It took the company just 15 months from planning to execution of the launch in Hyderabad. Reliance is watching the Hyderabad pilot closely and intends to fine-tune national rollout based on feedback received here. So far company executives appear gung-ho with the launch and are focused on saturating Hyderabad with 33 outlets next. The Aditya Birla Group is reported to be putting together a blueprint for the second largest investment in the Indian retail space. The group may invest upwards of US\$3 billion to set up 6,000 stores within three years, with the first stores targeted to open by middle of next year.

Pantaloon Retail, an earlier entrant to retail in India, has aggressive plans to double its retail space to 8 million $\mathrm{sq} \mathrm{ft}$ within a year and to 30 million sq ft 
by 2010. It has 33 Big Bazaar supermarkets and plans to open another 10 by November. Pantaloon Retail's Food Bazaar is currently the largest supermarket operator in India by value.

RPG Retail has 80 stores now with $500,000 \mathrm{sq}$ $\mathrm{ft}$ of retail space and plans to double this number within a year by expansion to smaller cities with the Spencer's Hyper, Super, Daily and Fresh brands. RPG also expects to be 10 times its current size within 5 years.

Godrej Agrovet and ITC (e-choupal) are large payers focusing on the rural sector. Godrej plans to launch 1,000 Aadhar stores in rural India by 2010.

\section{Foreign Majors Play Second Fiddle}

For now, foreign retailers can only enter India by licensing their names or selling franchises to local companies, a restriction that severely limits the expansion strategies of big-box stores such as Wal-Mart, Tesco or Carrefour. Eager to get a toehold in the Indian market, foreign majors are playing ball. Wal-Mart, and Tesco are reportedly in talks to partner the Bharti Group for retail operations in India via a master franchisee agreement. Wal-Mart is also believed to be in talks with the Aditya Birla group.

\section{Demand for Retail Real Estate to Soar}

Today, close to $95 \%$ of India's retail outlets are below $500 \mathrm{sq} \mathrm{ft}$, as compared to the 2,000 to 5,000 $\mathrm{sq} \mathrm{ft}$ Reliance Fresh stores and upcoming supermarkets of over 100,000 sq.ft. With over 1,000 hypermarkets and 3,000 supermarkets projected to come up by 2011, India will need additional retail space of 700 million sq ft as compared to today according to KSA Technopak. Current projections on construction point to a supply of just 200 million sq $\mathrm{ft}$. leaving a gap of 500 million sq ft., at a cost of US\$ $15-18$ billion.

\section{Winners and Losers}

As the Indian retail industry attempts to do in 10 years what other markets have taken 25-30 years to do, the consequences of India's retail revolution will be felt by all, from the farmer in a village to a shopper in a high-end mall. More important than the high-stakes battles being played out in corporate boardrooms is the social and economic impact that the Indian retail revolution will wreak. Make no mistake, there will be winners and losers as the retail landscape shifts.

Consumers will clearly win. Long used to shopping in crowded and dusty marketplaces, they will flock to the air-conditioned havens in droves, attracted by the convenience of one-stop shopping, a wide range of products to choose from, and significantly lower prices than they pay today. The savings will likely find their way back via higher consumption, helping drive the economy. Tax collections will also increase as more retail sales flow through the organized trade.

Farmers and other suppliers who are able to deliver against the stringent quality requirements placed on them by modern retail will benefit from higher prices as middlemen get cut out of the supply chain. Landowners and real estate developers will laugh all the way to the bank as multi-billion dollar investments compete for limited supply of space. Branded consumer goods companies are likely to face pricing pressures as well as competition from the retailer's own label brands. Perhaps most concerning is the impact large retailers will have on the small shop. Over 54 million people are estimated to work in 12 million small shops across the country, and as market share shifts to the modern trade, their livelihood could be at risk. KSA Technopak however believes that the impact on traditional retail will be limited to 300,000 to 500,000 shops in direct range of 4,000 hypermarkets and supermarkets and the consultancy predicts that the number of traditional retail stores will increase by 2015 .

\section{Future of Retailing}

\section{Green retailing}

Arguably the single most important issue for retailers today is the environment. Once considered a niche playing field, green retailing has moved from "nice to have" to "must have" as both customer and regulatory demands tighten for the industry. And some of the biggest players are leading the charge to more environmentally aware practices.

With the likes of Tesco, Coop as well as Sainsbury, Home Depot, Marks \& Spencer, Starbucks, Zara and Wal-Mart leading the way, not having a distinct environmental plan built into retail strategies has become the exception, where only a few years ago it was the rule. What to expect then in 2020? The need of the hour is premium payments for enviro-friendly products, more low-energy production and the creation of new - higher-standards for ethical trading.

\section{Individualized service}

Service and in-store experience continue to break out of the "one-size-fits-all" offering. Both are becoming more individualized and specialized for specific target 
groups. Today's shoppers are, of course, a highly differentiated demographic that promise to become even more so in the future. Working women, baby boomers, singles, teenagers and even children want products, services and shopping experiences that are as distinctive as they are. Leading retailers aim to satisfy these requirements by diversifying, hence the trend to "niche" stores.

In the future, service will become an even more finely-calibrated proposition between retailer and customer. And service components will evolve increasingly from reactive to predictive as retailers battle to win the loyalty of an ever-elusive-and more fragmented-customer base.

\section{High Performance in Retail: The International Scenario}

Accenture research identified five global retailers that outperform their peers. Analysis of these exceptional companies yields a set of core competencies which must be mastered to achieve the high performance they demonstrate.

Accenture fielded a research project to identify what characteristics the top five global high performers in retail share.

Competition between retailers is increasingly fierce. A fundamental problem is commoditization, with fully 74 percent of consumers saying that all stores look alike, while a third feel there is no differentiation between the various products and services. Most food retailers have experienced only single-digit growth over the past year and almost half of the industry's market value (44 percent) is based on future cash flow.

Despite this tough environment, some companies consistently achieve profitable growth. To find out how, Accenture initiated a global research project. Beginning with a global competitor set of 16 of the largest publicly held companies, Accenture identified five companies that had achieved high performance. These are Costco, Loblaws, Target, Tesco and Wal Mart.

\section{Key Findings}

Analysis of the five global hypermarkets that had achieved high performance showed mastery of six core competencies. While top retailers do not show equal mastery of all these competencies, high performance requires mastery of all six. These core competencies are:
1. Obsessive customer focus: High performers seek to please customers even when it does not make short-term economic sense.

2. Operational excellence: Retailers that have sought growth by entering emerging markets are particularly reliant on this characteristic. Operational excellence requires significant focus on the supply chain, since it comprises at least half of all non-store assets and can account for up to 70 percent of operating costs.

3. Strategic intent: More than a strong brand identity, this requires a clear and compelling strategy that permeates the whole company.

4. Innovation and commercialization: High performers take innovation beyond new products to include customer interactions and development of their own private label products.

5. Alliances and collaboration: The leveraging of sourcing relationships is emerging as a critical differentiator.

6. Talent management: In a people-centered industry, attracting and keeping the right talent is vital

\section{Going for growth}

Another hallmark for the future of successful retailers: growth in terms of the multiplicity of geographic, online and format offerings. Looking at Tesco as a harbinger of the future for retail, the company has an incredibly aggressive growth agenda. Through meticulous research and the ability to understand customers at a local level, Tesco then tailors offerings accordingly. Best Buy is another retailer driving a relentless growth agenda. Like Tesco, the expansion is being undertaken with the customer at heart, and the company is testing different operating models aimed at improving customer experience and ensuring a local touch from an international player. The company has also developed a strong online presence that is tightly integrated with their bricks and mortar operations. This customer-centric approach has steered the development of a robust multi-channel interface, with purchasing available in store, online or through call centers.

\section{Conclusions}

We have focused mainly on the likely positive impact of this revolution in different sectors is enumerated. The central idea of this paper is on how this retail boom would help the India. What we can 
predict won't change is the environment. The increasingly individualized store experience and growth and diversification of formats only will help the Indian retail sector to reach greater heights. Clearly these are all areas that will influence retailing through the next decade and beyond. Contemplating this increasingly complex, hyper-competitive world, it is somewhat comforting to note that one thing will never change in retail. There is a greater need for the companies that can react swiftly to market trends and respond relevantly to new customer behaviors. These kind of swift actions only will enable the players in this field to achieve high performance and growth despite marketplace conditions. The New York Times in a recent article on retailing in the country commented "No industry has more potential, if transformed, to resolve modern India's most pressing challenge: to enrich the poor." No matter who the individual winners and losers are, the country will win from India's retail revolution.

\section{TABLE ON QUICK STATISTICS FOR INDIAN RETAILING}

\begin{tabular}{|l|l|}
\hline Markets & Market size (total) 2006: US\$ 300 bn/annum \\
& Market size (total) 2010: US\$ 427 bn/annum \\
& Market size (total) 2015: US\$ 637 bn/annum \\
& Market size (modern retail) 2006: US\$ 9-12 bn/annum \\
& Market size (modern retail) 2011: US\$ 60 bn/annum \\
& Annual rate of growth (modern retail): $35 \%$ \\
& Penetration (modern retail) 2006: 3 to $4 \%$ \\
& Penetration (modern retail) 2010: $10 \%$ \\
& Number of retail outlets (total): $12 \mathrm{million}$ \\
\hline Investment & New Investment by 2011: US\$ $30 \mathrm{bn}$ \\
\hline Employment & No. of persons employed (total): $21 \mathrm{mn}$ \\
\hline Wealth & No. of new jobs in next two years: $2 \mathrm{mn}$. \\
\hline Retail Space & No. of dollar designated millionares in India(2006) 100,015 \\
& Typical space per outlet: 100 to $500 \mathrm{sq} . \mathrm{ft}$. \\
& Space occupied (modern retail): $35 \mathrm{mn}$ sq.ft. \\
& Operating Malls 2007: 114 (35 mn sq.ft.) \\
& New Malls under construction: 361 (117 mn sq.ft.) \\
& New space distribution: $65 \%$ (top 7 cities) \\
& New space distribution (among top 7 cities): NCR 34\% \\
\hline Note: Statistics, most of which is in the form of estimates, contained herein above, is based and published research/ news reports
\end{tabular}

\section{Select References:}

[1] Ernst \& Young, The Great Indian Retail Story, 2006.

[2] $\mathrm{FICCl}-\mathrm{ICICl}$ Property Services Study, New Delhi.

[3] Let gradualism guide FDI in retail, Economist, 2006.

[4] AT Kearney, GRDI, 2006.

[5] Economic Times, May 20, 2008

[6] Express Press Release, Consumer durables sector sees pick-up sales in India, 2006.

[7] www.accenture.com

[8] http://www.indiaretailbiz.com
L. Suresh Mallya Undergraduate in Mechanical Engineering, post graduate in Management, Foreign Trade, Economics and $\mathrm{M}$ Phil in Management. Currently doing $\mathrm{PhD}$ in Human Resource Management in Dr. MGR University, Chennai. 16 years industrial experience in the areas of Production, Marketing and

Sales in different industrial organizations and 12 years experience in the teaching field. Presently working as Assistant Professor in the Department of Management Studies in SRM Valliammai Engineering College, Chennai 